\title{
School as Stakeholder of Corporate Social Responsibility Program: Teacher's Perspective on Outcome in School Development
}

\author{
Maimunah Ismail • Ratna Fauzi Amat Johar • \\ Roziah Mohd Rasdi • Siti Noormi Alias
}

Published online: 27 July 2013

(C) The Author(s) 2013. This article is published with open access at Springerlink.com

\begin{abstract}
Knowledge of the outcome of corporate social responsibility (CSR) programs in school development in developing countries such as Malaysia is limited. This article examines types of CSR programs and the outcome on school development from the perspective of teachers. Data from a survey involving 273 teachers of schools that have participated in CSR programs, and data from focus group discussions with two groups of teachers were used in the analyses. The results of this exploratory study show that schools gained most from CSR programs in terms of improvement in the schools' physical infrastructure and facilities through funds provided, followed by provisions of reading materials for students and teachers in these programs. The results also revealed that the CSR programs contributed significantly to school development in terms of school living, student achievement, and school achievement.
\end{abstract}

Keywords Business corporation .

Corporate social responsibility $\cdot$ School development

M. Ismail ( $₫)$ · R. F. Amat Johar · R. Mohd Rasdi · S. N. Alias Department of Professional Development and Continuing

Education, Faculty of Educational Studies, Universiti Putra

Malaysia, 43400 UPM Serdang, Selangor, Malaysia

e-mail: mismai1379@gmail.com; mismail@educ.upm.edu.my

R. F. Amat Johar

e-mail: ratnafauzi71@yahoo.com

R. Mohd Rasdi

e-mail: roziah.mr@gmail.com

S. N. Alias

e-mail: noormiey@gmail.com

\section{Introduction}

Corporate social responsibility (CSR) programs are initiatives that business companies undertake to integrate social and environmental concerns into their business operations and interact with their stakeholders on a voluntary basis (Dahlsrud 2008). Based on "waves of CSR" (Chapple and Moon 2005), there has been a rapid spread of CSR programs in developing countries resulting from globalization, with community involvement as one of the focal areas of these programs and school as one of the stakeholders because school is a community constituent. School as a stakeholder shows the significance of CSR as a program in developing school through which various financial and human resources are channeled. It is more evident based on the Malaysian CSR award recipients in 2010 (Prime Minister's CSR Awards 2010) that school development is one of the criteria of success of CSR programs other than changes in the environment, culture and heritage, community development, and workplace practices. The educational community as one of the stakeholders in CSR programs, however, seems to have been neglected as a research subject. Due to its broad meaning, the term CSR used in this article could mean a program, an initiative, or any working together between a corporation and a school through which win-win benefits are gained by both parties.

\section{The Research Context and Research Questions}

Internationally, the majority of CSR studies in education has been conducted at institutions of higher learning in western contexts (Borel et al. 2011; Naeem and Peach 2011), and several studies on schools have addressed such factors as the characteristics of "education for sustainable development-promoting" strategies in China's basic 
education (Wang 2011) and practices of integrating the earth charter into education activities in Germany (Mathar 2010). The aforementioned studies, however, did not address elements of CSR in school development. Thus, it is obvious that the school community, particularly teachers as one of the CSR stakeholders has not been taken into account as a research subject, particularly in Malaysia.

The available research in CSR programs in Malaysia are limited such as on CSR program disclosures of industrial companies (Mohd Ghazali 2007) in which disclosures were mainly made through companies' websites and annual reports. Another study on stakeholders' perception of CSR programs based on an Islamic context (Siwar and Hossain 2009) showed that some of the program orientations are similar with the Islamic tenets of being ethical, adhering to legal procedures, and helping the community. Abdul Rashid and Ibrahim's (2002) study showed that $93.1 \%$ of sampled managers are relatively aware of CSR programs; however, they do not fully comprehend the importance of CSR programs. Siwar and Md Harizan's (2009) study on CSR practices of corporations showed that most CSR commitment was expressed in terms of charity, despite a better awareness on the importance of these programs to the community. An analysis on CSR programs in community development (Ismail 2009) shows that the programs have been widespread in the developed countries but Malaysia is just beginning to embark on these initiatives to help government in community development. The only education-related study in Malaysia is on an environmentfriendly chemistry teaching method course of pre-service teachers at a public university (Karpudewan et al. 2011), in which the study revealed the impact of the experience on student-teachers interaction led to the pre-service teachers to be intrinsically motivated in committing pro-environmental actions.

Despite the proliferation of research on CSR programs, evidence on the benefits of these programs to the educational community remains unclear. The need for more research on CSR programs to unravel the intricate relationships between businesses and communities, including schools, has been suggested (Lee 2008). For this reasons, this exploratory study addresses the following research questions specifically from the perspective of teachers:

(i) What types of contribution are received by the schools participating in CSR programs?

(ii) What are the levels of the orientation of CSR programs in relation to economic, legal, ethical, and philanthropic responsibilities?; and

(iii) How to explain the contributions of the corporations in CSR programs to school development?

An investigation of these issues is significant because it contributes empirically on the types of provisions delivered by CSR programs providers and to see whether the provisions lead to school development. The study is vital, particularly in seeing the reality of CSR programs through which it shows the response of corporations to government's call for their increased involvement in school development as stipulated in the New Economic Model (NEM) of Malaysia.

In the next section, we continue to present the relational theory underlying CSR programs in this study, as well as their orientation and contribution to school development. We then proceed with the methodology and results of the study, followed by a conclusion and recommendations for practice and future research.

\section{Relational Theory of CSR}

The relational theory underlying CSR programs has its root in the complex firm-environment relationships (Secchi 2007). The theory consists of four sub-theories: (i) business and society; (ii) stakeholder approach; (iii) corporate citizenship; and (iv) the social contract. In this study, only the "business and society" and "stakeholder approach" subtheories are relevant. "Business and society" refers to "business activities in society" in which CSR programs emerge as a result of the interaction between the two entities. One of the measures of CSR programs is of the gains that the community, including schools, has from CSR programs. The stakeholder approach has been developed as one of the strategies for improving the management of CSR programs firms in dealing with, for instance, the school stakeholders such as teachers. The way in which the stakeholders perform their tasks in CSR programs depends on their perception, such as on the CSR orientations of economic, legal, ethical, and philanthropic responsibilities. The stakeholder approach also emphasizes the integration of school demands and the right actions to take to achieve a responsible society (Garriga and Mele 2004). The stakeholder approach is expected to arrive at a win-win situation between the corporation and the stakeholders, one of which is the school community including teachers.

\section{CSR Orientation and Contribution to School Development}

"CSR orientation" refers to Carroll's (Carroll and Shabana 2010) classic framework of CSR program orientation, which consists of economic, legal, ethical, and philanthropic responsibilities, structured in the form of a pyramid (Fig. 1). Economic responsibility, the foundation of the pyramid, is a core function of the corporation as perceived by every stakeholder in society. Legal responsibility, which is structured above economic responsibility, signifies that corporations perform their economic responsibility within 
the government's rules and regulations. Ethical responsibility, which rests on top of both legal and economic responsibilities, pertains to practices expected by the society from corporations. Philanthropic responsibility, positioned at the top of the pyramid, concerns the firm's action to respond to societal expectations for good corporate citizens. CSR orientation is used in this study because such an orientation is crucial in gaging the perception of the school teachers involved in CSR programs, and this response affects CSR programs' sustainability in the education sector.

Community expectations regarding CSR program are important, as shown in Nigeria, where the local community expected to get sponsorship from a mining MNC for the renovation of schools, provision of employment and basic infrastructure such as roads and hospitals (Idemudia 2007). Studies on "industry-school partnership" are also used to support the significance of CSR orientation as perceived by school stakeholders such as teachers because the philosophy, goals and approaches of "industry-school partnership," and CSR are similar. In addition, the word "partnership" is often used to describe a business entity where partners share the profits or losses of the business undertaken (Keitel 2008). Furthermore, CSR is a relatively new phenomenon, and partnerships were used much earlier in practice (Idemudia 2007), particularly in developing countries. For instance, a partnership between a higher education institution and the call-center industry in the Philippines enables the former to broaden employment opportunities for its graduates in the emerging industry, while the latter helps to improve the quality of English teaching and to provide industry-based technologies in the institution's laboratories (Keitel 2008). Partnerships have emerged recently in many countries as a policy solution for managing school-to-work transitions for youth (Cushla and Hay 2009) in cooperation with parents, schools, and universities, affecting students' curriculum enrichment and teachers' professional development (Weller and Dillon 1999). A partnership environmental project has benefited schools through curriculum development and learning through field visits in Japan (Chikami and Sobue 2008) and financial assistance to needy school students in Indonesia (Mitsui and Co. 2012).

Forms of CSR programs that contribute to Malaysian school development are diverse that include school adoption, ICT enhancement, scholarship programs, and nurturing knowledge outside classrooms. Telekom Malaysia (TM) provides ICT facilities and scholarships benefitting students and teachers. In the long run, this should help the country's effort to bridge the urban-rural school digital divide. The national petroleum corporation (Petronas) has launched an interactive science discovery center, known as Petrosains, to introduce the science and technology of the industry to school children. The Rashid Hussain Banking (RHB) Group has sponsored Spell-It-Right competitions to improve students' language skills in English and Malay. Hence, this study attempts to examine empirical evidence regarding specific CSR initiatives, CSR orientation, and the extent to which the initiatives contribute to school development as perceived by teachers.

\section{Methods}

Population, Sampling Procedure, and Data Collection

Figure 2 depicts the sampling and data collection procedures of the study. The sampling frame includes 112 schools that have been participating in CSR programs since 2007, representing the eastern, western, northern, and southern regions of Peninsular Malaysia. The names of the schools were obtained from related online databases and annual reports of companies' CSR programs. Using a cluster random sampling technique, 36 schools were
Fig. 1 Pyramid of CSR orientations. Source adapted from Carroll and Shabana (2010, p. 90)

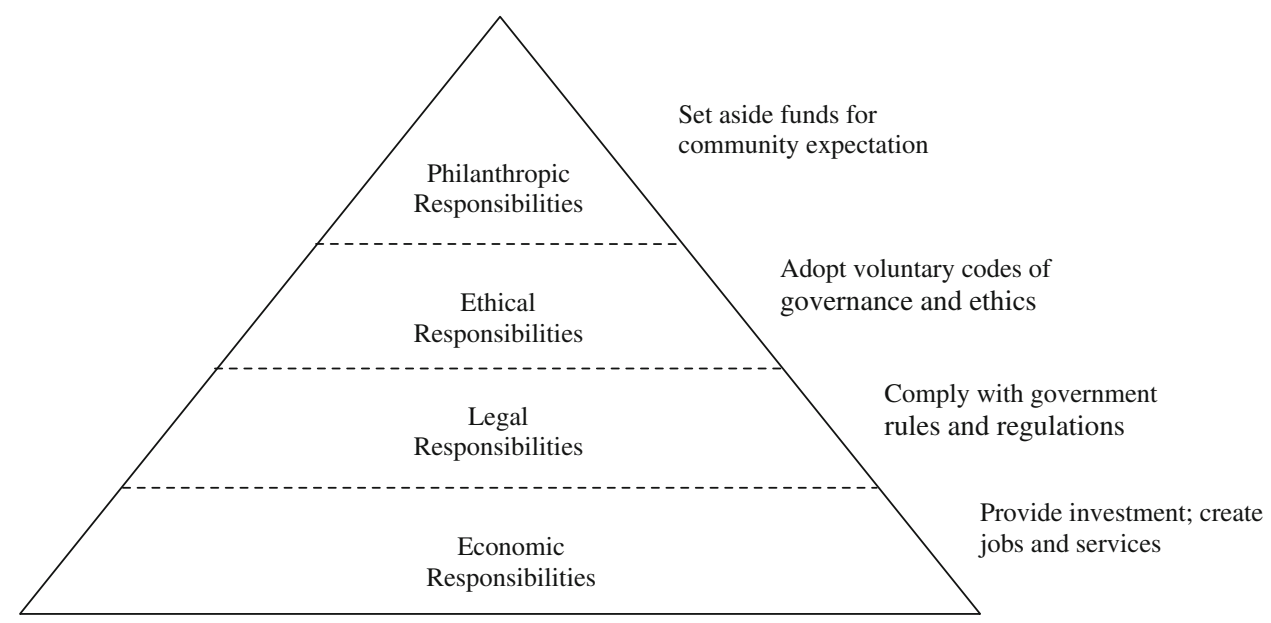


selected randomly from the four regions. The regions were divided based on the country's National Corridor Economic Region Plan of Malaysia (NCER), which consists of two phases: Phase 1 and Phase 2. The inclusion of these phases implies that corporations are expected to increase their CSR initiatives in line with the country's NEM, as NCER is one of the core strategies. The number of teachers who participated in CSR activities in each school ranges from 5 to 10 ; hence, the median value for participation is 7.5. As the unit of study analysis is the teacher, therefore, the estimated total population for this study was 840 teachers (or $112 \times 7.5$ ). The sample size was determined using Krejcie and Morgan's (1970) and Sampsize's (2005) procedures, resulting in 265 and 264 respondents, respectively. As a survey response rate is usually relatively small compared to other methods of data collection (Leedy 1997), we distributed a total of 300 questionnaires. Finally, 273 respondents completed the questionnaires and were used for the analysis.

Additional data collection was executed using focus group discussion (FGD) (Krueger and Casey 2009). FGD is a qualitative technique in which a group of people are asked about their perceptions and opinions regarding a topic of interest. FGD considers the specificity of responses, and it has advantages in that it captures real-life data in a social environment, high face validity, and speedy results. The purpose of FGD in this study was to ascertain the teachers' opinions on the specific contributions of CSR
Fig. 2 Sampling and data collection procedures

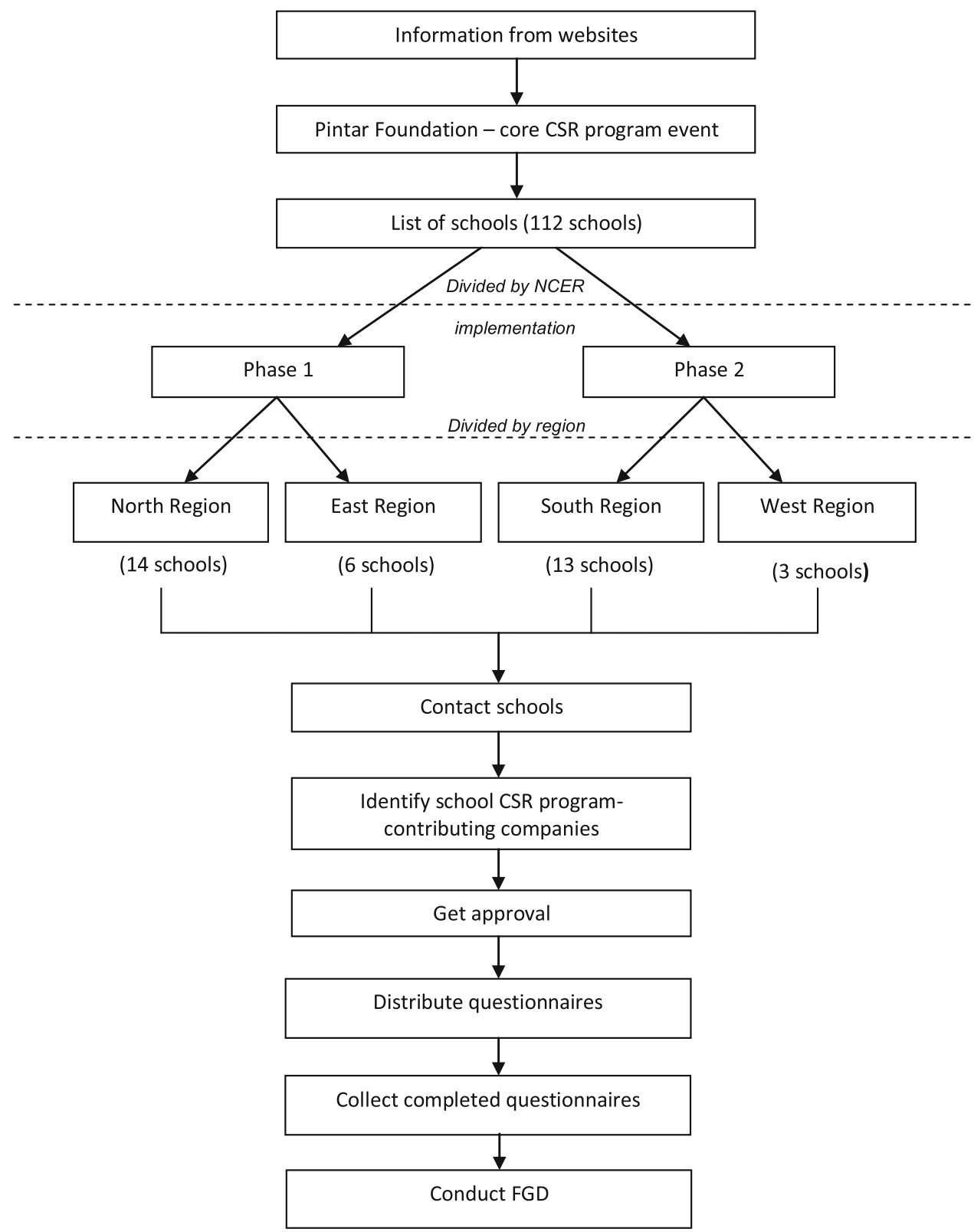


programs to school development (school living, student achievement, and school achievement). The technique involved two FGD sessions involving 18 teachers from two CSR-adopted schools of a corporation in the earlier survey. Three digital tape recorders were used to record the opinions of the teachers regarding questions posed by the researchers during the FGD sessions.

Permission was requested from the Ministry of Education and the state education departments prior to data collection. The survey used "drop-and-pick" technique. The study analyses adopted descriptive statistics for the survey data and constant comparative technique for the FGD data.

\section{Instrument}

The instrument of the survey study was a questionnaire consisting of three sections. Section A on school development addresses the three components of school living, student achievement, and school achievement (Canada 2010). These components are found to be affecting the development of schools holistically, as school living concerns the environment in and outside class, student achievement relates to interaction between students and teachers through teaching and learning, and school achievement is the consequence of actions and activities in school involving teachers. Using a seven-point Likert scale ( $1=$ "absolutely untrue" to $7=$ "absolutely true"), teachers were required to indicate their agreement on items regarding school development after receiving the contributions from companies. Sample items included the following: (i) school living_- "The CSR programs enhance school compound beautification"; (ii) student achievement- "The CSR programs assist in increasing students' writing skills"; and (iii) school achievement- "The CSR contributions enhance schools' reputation through students' academic achievement."
Section B, concerning CSR program orientation, was adapted from Aupperle et al. (1985) and consists of items on economic, legal, ethical, and philanthropic responsibilities. The respondents were required to respond to a seven-point Likert scale ( $1=$ "absolutely untrue" to $7=$ "absolutely true"). Sample items included the following: (i) economic"It is important for CSR programs to maintain a strong competitive position"; (ii) legal- "It is important for CSR programs to comply with various federal, state, and local regulations"; (iii) ethical- "It is important for CSR programs to perform in a manner consistent with the expectations of societal ethical norms"; and (iv) philanthropic"CSR programs should voluntarily assist projects to enhance the school community's quality of life."

Section C addresses respondents' socio-demographic profiles and the quantitative responses on the types of CSR programs contributions from companies. The instrument was prepared in both English and Malay (the Malaysian national language). Table 1 shows the Cronbach's alpha for the pre-test and the actual study. A total of 30 respondents involved in the pilot study through which the instrument was also validated. Questions in the FGD were mainly concerned with the issue of how the contributions of the corporation in CSR programs led to school development.

\section{Profile of the Research Subject}

The demographic profiles of the survey respondents show that they are about equally distributed over the age range from 26 to 46 years $(\mathrm{M}=39.30 ; \mathrm{SD}=8.46)$ and that the majority $(85 \%)$ are married and female $(67 \%)$. Most of the respondents $(89 \%)$ are teachers with a bachelor's degree (52\%), and more than half (58\%) have between 11 and 30 years of work experience with an average of 14.64 years.

Table 2 shows the profile of the 18 informants in the FGD, nine are from a secondary school (school A) and another nine from another primary school (school B). The
Table 1 Cronbach's alpha for pre-test and actual survey

\begin{tabular}{|c|c|c|c|c|}
\hline \multirow[t]{2}{*}{ Scale } & \multicolumn{2}{|c|}{ Pre-test $(n=30)$} & \multicolumn{2}{|c|}{ Actual study $(n=273)$} \\
\hline & $\begin{array}{l}\text { Number of } \\
\text { items }\end{array}$ & $\begin{array}{l}\text { Cronbach's } \\
\text { alpha }\end{array}$ & $\begin{array}{l}\text { Number of } \\
\text { items }\end{array}$ & $\begin{array}{l}\text { Cronbach's } \\
\text { alpha }\end{array}$ \\
\hline \multicolumn{5}{|l|}{ CSR orientation } \\
\hline Economic & 5 & 0.73 & 5 & 0.96 \\
\hline Legal & 5 & 0.76 & 5 & 0.95 \\
\hline Ethical & 5 & 0.78 & 5 & 0.96 \\
\hline Philanthropic & 5 & 0.71 & 5 & 0.95 \\
\hline \multicolumn{5}{|l|}{ School development } \\
\hline School living & 15 & 0.94 & 15 & 0.95 \\
\hline Student achievement & 15 & 0.82 & 15 & 0.95 \\
\hline School achievement & 12 & 0.86 & 12 & 0.96 \\
\hline
\end{tabular}


age ranges from 29 to 53 years, work experience ranges from four to 30 years, and eight are male and ten female with education ranges from certificate in basic education to master's degree. Both schools received CSR programs contributions from TM, a telecommunication corporation.

\section{Results and Discussion}

\section{CSR Practices in School Development}

Table 3 shows data on respondents according to the core business of companies and types of CSR programs on the three components of school development. The respondents are from 10 companies representing seven core businesses. Banking is the core business that represents the greatest number of companies participating in school CSR activities. These companies mostly contributed funds to schools to finance expenses to improve the physical infrastructure and facilities, such as the fences, canteens, walls, and landscape of schools (83.2\%). The next most frequent form of CSR initiative is the provision of reading materials for both students and teachers in schools through their resource centers $(72.2 \%)$, followed by school uniforms and stationery for students $(66.7 \%)$. The next most prominent forms of CSR initiatives are training, field trips, workshops, and competition programs, such as Spell-ItRight and English workshops (61.2\%); tuition classes
(42.9\%); ICT facilities (33.3\%); sports equipment $(23.1 \%)$; and sports programs $(17.6 \%)$.

The increased number of companies that participated in Malaysian CSR programs in the first decade of the millennium particularly in school development is due to internal and external factors. The internal factors are events within Malaysia, such as the setting up of CSR guidelines by the Bursa Malaysia framework in 2006, the emergence of the Silver Book in 2006, and CSR awards in 2007, as well as several acts that have been in place since the 1970s, such as the Anti-corruption Act (1977) and the Human Rights Commission of Malaysia Act (1999) (Lu and Castka 2009; PEMANDU 2010). The external factors are influences coming from abroad, such as CSR waves from the developed countries, the spread of MNCs into developing countries, and the emergence of the Global Compact Network Malaysia resulting from globalization (Chapple and Moon 2005).

\section{CSR Orientations and School Development}

The perceived CSR programs orientations used were based on Carroll's classic CSR pyramid of economic, legal, ethical, and philanthropic responsibilities (Carroll and Shabana 2010) and analyzed descriptively. The highest orientations, based on mean score, are legal $(M=5.86$; $\mathrm{SD}=1.18)$ and philanthropic $(M=5.86 ; \quad \mathrm{SD}=1.11)$ responsibilities, followed by economic $(M=5.58$;
Table 2 Informants in the focus group discussion

\begin{tabular}{|c|c|c|c|}
\hline Age (year) & Gender & Highest education & $\begin{array}{l}\text { Work experience } \\
\text { (year) }\end{array}$ \\
\hline \multicolumn{4}{|l|}{ School A } \\
\hline 53 & Female & M.S. (Malay Language) & 30 \\
\hline 33 & Female & M.S. (Planning) & 5 \\
\hline 29 & Male & B.Edu. (Information Technology) & 4 \\
\hline 33 & Male & B.S. (Islamic Studies) & 13 \\
\hline 31 & Male & B.Edu. (Information Technology) & 10 \\
\hline 45 & Female & Diploma (Education) & 13 \\
\hline 53 & Female & Diploma (Education) & 28 \\
\hline 30 & Male & Diploma (Education) & 5 \\
\hline 43 & Male & Diploma (Education) & 15 \\
\hline \multicolumn{4}{|l|}{ School B } \\
\hline 38 & Female & Higher School Certificate Diploma (Education) & 15 \\
\hline 34 & Female & B.Edu. (Mechanical Engineering) & 13 \\
\hline 40 & Female & B.Edu. (Mathematics) & 15 \\
\hline 46 & Male & Certificate in Basic Education & 22 \\
\hline 43 & Male & B.Edu. (Mathematics) & 18 \\
\hline 34 & Female & B.S. (Dev. Management) Diploma (Education) & 6 \\
\hline 47 & Male & B.Edu. (Science) & 23 \\
\hline 40 & Female & B.Edu. (Science) & 18 \\
\hline 44 & Female & Diploma (TESL) & 22 \\
\hline
\end{tabular}


Table 3 Respondents according to core business of companies and types of CSR programs on school development $(n=273)$

\begin{tabular}{|c|c|c|c|c|c|c|c|c|c|c|}
\hline \multirow[t]{3}{*}{ Core business } & \multirow[t]{3}{*}{ Companies } & \multicolumn{9}{|c|}{ CSR contributions on school development dimensions } \\
\hline & & \multicolumn{4}{|c|}{ School living } & \multicolumn{4}{|c|}{ Student achievement } & \multirow{2}{*}{$\begin{array}{l}\text { School } \\
\text { achievemen } \\
9\end{array}$} \\
\hline & & 1 & 2 & 3 & 4 & 5 & 6 & 7 & 8 & \\
\hline \multirow[t]{4}{*}{ Banking } & CIMB & 47 & 48 & 48 & 48 & 48 & 48 & 48 & 48 & 48 \\
\hline & RHB & 17 & - & 12 & - & - & - & - & - & - \\
\hline & Affin Bank & - & 15 & - & - & - & - & - & - & - \\
\hline & Bank Islam & 15 & - & 15 & - & 15 & - & 15 & 15 & - \\
\hline Telecommunication & Telekom Malaysia (TM) & - & 28 & 28 & - & 15 & 28 & - & 15 & - \\
\hline Plantation & Sime Darby & 63 & 15 & 49 & 15 & 49 & 15 & 24 & 49 & - \\
\hline Automotive & UMW Toyota & 15 & - & 15 & - & 15 & - & 15 & 15 & - \\
\hline Shipping & $\begin{array}{l}\text { Boustead Heavy Industries } \\
\text { Group }\end{array}$ & 25 & - & 25 & - & 10 & - & - & 25 & - \\
\hline Media & Media Prima & - & - & 20 & - & - & - & - & - & - \\
\hline Chemical products & CCM Chemical Sdn. Bhd. & 15 & - & 15 & - & 15 & - & 15 & 15 & - \\
\hline Total (percentage) $)^{\mathrm{a}}$ & & $\begin{array}{l}197 \\
(72)\end{array}$ & $\begin{array}{l}106 \\
(39)\end{array}$ & $\begin{array}{l}227 \\
(83)\end{array}$ & $\begin{array}{l}63 \\
(23)\end{array}$ & $\begin{array}{l}167 \\
(61)\end{array}$ & $\begin{array}{l}91 \\
(33)\end{array}$ & $\begin{array}{l}117 \\
(43)\end{array}$ & $\begin{array}{l}182 \\
(67)\end{array}$ & $\begin{array}{l}48 \\
(18)\end{array}$ \\
\hline
\end{tabular}

1 Reading materials, 2 ICT facilities, e.g., computer units or computer labs, 3 funds for school facilities, e.g., fence, canteen, or landscape, 4 sports equipment, e.g., rackets and balls, 5 programs (competition), e.g., Spell-It-Right program, 6 ICT classes, 7 fees for tuition classes, 8 school equipment, e.g., stationery or school uniforms, 9 sports and outdoor programs, e.g., sports day or study visits

${ }^{a}$ Total and percentages in the row are not summative

$\mathrm{SD}=1.28) \quad$ and ethical responsibilities $\quad(M=5.45$; $\mathrm{SD}=0.83$ ). However, the sequence of the CSR orientations is not similar to that of the classic CSR pyramid. Legal responsibility is the highest as perceived by the respondents. This implies that the respondents highly expected corporations to strictly follow the rules of behavior considered appropriate by society as specifically stated in legal rules, whether related to consumer, environment, market, or employment laws. This shows that the respondents are able to perceive that companies should adhere to the laws and regulations of the locality where the business operates. Being educated, respondents who are teachers, most of whom obtained a tertiary education, have high expectations that companies should strictly follow the rules of behavior considered appropriate by society, including schools. Legal responsibility was similarly perceived as highest by consumers in Singapore (Tan and Komaran 2006) and managers in England, France, Germany, Japan, Sweden, Switzerland, and the US (Visser 2008).

Philanthropic responsibility was highly perceived by the study respondents. There is a strong indigenous tradition of philanthropy, and in Malaysia, it is the old form of CSR initiative known by the society (Ismail 2009). Furthermore, in the past five decades, many developing countries have become familiar with donor assistance; hence, there is an ingrained culture of philanthropy in the community, including teachers. Philanthropy is almost synonymous with CSR program because, generally, developing countries are still at an early stage of the program (Visser 2008).

However, ethical responsibility is the lowest, which shows that the respondents have a low level of perception that businesses should avoid harm to the community. This concurs with Visser's (2008) findings regarding CSR orientation such that, in developing countries, ethics seems to have the least influence on CSR movements. Furthermore, ethical responsibility is understood to be a newer notion of the social contract between business and society compared to traditional philanthropic responsibilities (Carroll and Shabana 2010). Another Malaysian study found that philanthropic orientation was the strongest predictor of CSR participation among managers, while ethical orientation was the weakest (Abdul Rahim et al. 2010).

\section{CSR Contribution and School Development}

The results of FGD-generated themes regarding the impact of CSR initiatives on school development, specifically in the respective areas of school living, student achievements, and school achievement, are presented next.

\section{(i) School Living}

School living refers to the school environment that makes the surroundings more conducive to students' learning. One drastic change brought about by the CSR program is in the development of school computer 
laboratories. An informant from School A articulated her reflection:

A drastic change was when this school was equipped with a new computer laboratory with more computer units. That lab becomes a new physical structure of this school, replacing the old room with only several computers. An important consequence is one new subject was created, called "Information Communication Technology Literature (ICTL)" for Form 1 and 2 classes. A trained teacher in ICT is assigned to handle this subject.

Another informant recalled another major improvement to school living resulting from the CSR program.

The school surrounding becomes beautiful with newly painted walls and decorations, and landscape. This is an indirect impact of events such as the attendance of representatives from TM, the District Office, etc., at the opening ceremonies of events such as Earth Camp and Green Fest and other environmental programs ... Furthermore, there were budgets to plant greenery in the school compound.

\section{(ii) Student achievement}

Student achievement was found to be the highest-impact CSR program by the informants. Student achievement refers to a wide range of positive changes experienced by students resulting from their participation in CSR programs, not only in examinations but also in co-curricular activities involving soft skill development. In relation to examination, this is shown in the overall performance of the students in the Lower Certificate of Examination (LCE) in 2011. Two informants from School A and B each expressed:

The school grade average (SGA) of this school was 2.17 in 2011, improved from 2.53 in 2010 (scale from 1 to 4 where 1 is the maximum and 4 the minimum) ... this made this the best school in LCE for 2011 in this district ... Furthermore, one student obtained 9As (all distinction), which the school had not had for the past 10 years ... We felt this was very rewarding.

In 2010 there were only five students who obtained 5As (all distinction) in the Primary School Examination and it has increased to 12 students in 2012.

Many schools nowadays target soft skill development as one of the indicators of student achievement. In relation to how CSR program has impacted students' soft skill development, four informants from School A shared their experience clearly:
I noticed students became more active, brave ... When there are performances such as Nasyid (a religious choir), without hesitation, many students volunteered to participate.

I have noticed, especially among the Form 5 students that they were active in participating in competitions. For instance, they received second place in a choral competition for two consecutive years in 2011 and 2012 for this district.

Students (especially in Form 5) were aware that outdoor (co-curricular) participation adds to their overall performance $(10 \%)$ later in major exams (School Certificate of Education or MCE). That is why they were responsive to joining outdoor camping, such the trips to Ulu Yam and Morib, both in Selangor, last year.

In English competitions, students participated in debates, storytelling ... which TM personnel helped a lot in running the programs ... students competing with each other to show their best ... I noticed that some have changed ... they became very brave, no longer shy as before when it comes to communicating in English. Not only that, but, in certain competitions, they themselves searched for information or data using the Internet for the competitions...

An informant from School B shared her observation on important change to students' soft skill:

Students' involvement in developing robotic projects not only made them interested in science subject, they became more confident, brave and able to work in teams ...

\section{(iii) School Achievement}

When it comes to school achievement, it is about not only students but teachers as well. It is inevitable that any positive changes observed among students were similarly felt by the teachers, as the two groups function symbiotically in a school. An informant from School A revealed this succinctly:

The indirect impact of CSR is relating to the development of human capital in the short and long terms. Students improved their learning performance through exposure to environment issues, enhancement in social skills such as leadership and teamwork, etc ... On the other hand, teachers received training in ICT applications, such as developing home pages, emails, using databases in information searches ... including computer maintenance skills. 
Not only that, when there is an important/grand event involving CSR programs, teachers will be deployed in the planning and implementation (by involving students) until the end of the event. So they also learned skills in event management! As a result of this, some teachers become innovative. They always ask, 'What is the next event?' ... Of course, the budget must be there!

Teachers also gained hands-on skills relating to their daily tasks using computers. An informant from School A explained the change she has experienced and the changes she observed in others:

Since TM came into this school, any time when TM needs information quickly, I have no choice but to use emails - for communication with my colleagues which I never did before ... teachers became motivated in implementing the activities of TM. Many were eager for the involvement in field trips such as mountain hikes while planting trees and observing flora and fauna in the jungle. Teachers were also involved in performance events. Before this, no male teachers played musical instruments, and female teachers sang songs. Teachers were also involved in home page competitions among TM-adopting schools ... three teachers won a bronze medal.

An important issue of school achievement is its future potential from CSR programs. Positive remarks were made by two informants from School $\mathrm{A}$ and an informant from School B, respectively:

What is next? There will be a Memorandum of Understanding between TM and the Pintar Foundation of the Ministry of Higher Education Malaysia for follow-up activities involving TM-adopting schools in Malaysia. This initiative will be spearheaded by the Multimedia University in Cyberjaya (a university owned by TM). An important gain to be felt is that students from the schools will get a discount of $25 \%$ to $50 \%$ of university admission fees depending on their SPM results.

Recently, many parents in the local villages wanted to send their students here, but our classrooms and hostels are limited. Other organizations, such as the Rubber Smallholder Development Authority (RISDA), are eying for involvement with this school for tuition classes in science, mathematics, and English. Those are exhilarating outcomes!

Most parents allowed their children to participate in evening and weekend classes that we organized ... because they are convinced of this school improved performance for the past three years ... we have to continue these activities till the year ends...

\section{Conclusions and Recommendations}

Economic responsibilities still get the most emphasis, as perceived by the teachers in this study, in terms of their influence on school development. This conclusion concurs with Carroll's (2004) CSR pyramid after incorporating the notion of stakeholders such that CSR program is expected to do what is required by the global economic players. Ethical responsibilities are found to have a lower priority in this study. This is similar to the findings of Visser (2008) in developing countries, where ethics remains the lowest CSR priority. This can be explained in relation to a culture of less sensitivity to ethics as well as the lack of monitoring and ethics training among the CSR programs stakeholders (Visser 2008).

The study concludes that educational-related programs that form one of the dominant types of CSR are diverse, ranging from for school infrastructure, such as computer labs, to the provision of learning materials for students as well as professional development for teachers. Thus, CSR effort is manifested as a means and an end for some Malaysian corporations to help an important stakeholder, the school community. It is very appropriate for companies to use schools as their CSR entry points because students and teachers are considered "the audience in captivity" of the program, as it is more difficult to involve individuals from the community at large.

The FGD data show that CSR program is significant because it helps student achievements in diverse areas, academically and socially. It has indeed acted as a medium for nurturing knowledge outside classrooms due to its multidimensionality in practice involving fields such as ICT, the environment, languages, and life sciences. The study further concludes that CSR-implementing companies in Malaysia cover a wide range of core businesses, led by the banking and telecommunication sectors. The nature of the CSR activities delivered to schools depends on the type of business they are operating. This is evident in the fact that TM helped the sponsored schools in the areas of telecommunication and ICT. This is logical because, through CSR programs, core knowledge and technologies from the companies are transferred to the schools by specialists in the area for their good use.

Involving the younger population of a country (i.e., students) in CSR program has an advantage because it can act as an eye-opener to the students in terms of reality in future employment options (Keitel 2008; Cheung 2008). Students gain the required employability skills, such as 
teamwork, not only through the structured curriculum but also through students' exposure to the companies.

Another conclusion is that most companies began their CSR initiatives in the first decade of the millennium, inevitably resulting from globalization and the country's ambitious Vision 2020. We are optimistic that more MNCs and local corporations will come forward to participate in school-based CSR programs considering its multiplier effects on the students, teachers, and society.

This study is limited to teachers' perceptions on CSR program and its link with school development. It is also necessary to conduct a longitudinal study on the process and impact of CSR programs based on selected schools because these are long-term processes involving companies, schools, and the relevant NGOs. Studies are also suggested on the patterns of partnership among them and the types of local adaptations, which the MNCs have to consider in their endeavors. Finally, evaluation of CSR programs involving CSR providers and participants from public and private schools is suggested due to differences in resource endowment, the results of which should be useful for future practice.

Acknowledgments The research was funded by Research University Grant Scheme (RUGS) 2010-2012, Grant No: 06-04-10-1019RU of Universiti Putra Malaysia.

Open Access This article is distributed under the terms of the Creative Commons Attribution License which permits any use, distribution, and reproduction in any medium, provided the original author(s) and the source are credited.

\section{References}

Abdul Rahim, R., Jalaludin, F. W., \& Tajuddin, K. (2010). Consumer behaviour towards corporate social responsibility in Malaysia (pp. 1-17). Kuching: Conference Master.

Abdul Rashid, M. Z., \& Ibrahim, S. (2002). Executive and management attitudes towards corporate social responsibility in Malaysia. Corporate Governance, 2(4), 10-16.

Aupperle, K. E., Carroll, A. B., \& Hatfield, J. D. (1985). An empirical examination of the relationship between corporate social responsibility and profitability. Academy of Management Journal, 28(2), 446-463.

Borel, R., Cawagas, V., Jimenez, A., \& Salvetti, N. (2011). Education for sustainable development at the university for peace. Journal of Education for Sustainable Development, 5(2), 245-249. doi: 10.1177/097340821100500214.

Canada. (2010). School development in the province of Newfoundland and Labrador. Retrieved January 14, 2011 from http:// www.edu.gov.nf.ca/schooldev/default.htm.

Carroll, A. B. (2004). Managing ethically with global stakeholders: A present and future challenge. Academy of Management Executive, 18(2), 114-120.

Carroll, A. B., \& Shabana, K. M. (2010). The business case for corporate social responsibility: A review of concepts, research and practice. International Journal of Management Reviews, 12(1), 85-105. doi:10.1111/j.1468-2370.2009.00275.x.

Chapple, W., \& Moon, J. (2005). Corporate social responsibility (CSR) in Asia: A seven-country study of CSR web site reporting. Business \& Society, 44(4), 415-441. doi:10.1177/000765030 5281658.

Cheung, C. K. (2008). Practicing entrepreneurship education for secondary pupils through the operation of New Year stall in Hong Kong. The Asia-Pacific Education Researcher, 17(1), $15-31$.

Chikami, S., \& Sobue, K. (2008). Creating a sustainable city through a system of citizen-based learning: ESD at Nagoya Open University of the environment. Journal of Education for Sustainable Development, 2(2), 127-139. doi:10.1177/0973408 20800200210.

Cushla, K., \& Hay, S. (2009). Industry school partnerships: Reconstituting spaces of educational governance. Globalisation, Societies and Education, 7(2), 203-216.

Dahlsrud, A. (2008). How corporate social responsibility is defined: An analysis of 37 definitions. Corporate Social Responsibility and Environment Management, 15(1), 1-13. doi:10.1002/csr.132.

Garriga, E., \& Mele, D. (2004). Corporate social responsibility theories: Mapping and territory. Journal of Business Ethics, 53, 51-74.

Idemudia, U. (2007). Community perceptions and expectations: Reinventing the wheels of corporate social responsibility practices in the Nigerian oil industry. Business and Society Review, 112(3), 369-405.

Ismail, M. (2009). Corporate social responsibility and its role in community development: An international perspective. The Journal of International Social Research, 2(9), 199-209.

Karpudewan, M., Ismail, Z. H., \& Mohamed, N. (2011). Green chemistry: Educating prospective science teachers in education for sustainable development at school of educational studies, USM. Journal of Social Science USM, 7(1), 42-50. doi: $10.3844 /$ jssp.2011.42.50

Keitel, R. (2008). A proposed model of higher education institutioncall center industry partnership. The Asia-Pacific Education Researcher, 17(2), 203-214.

Krejcie, R. V., \& Morgan, D. W. (1970). Determining sample size for research activities. Educational and Psychological Measurement, 30(3), 607-610.

Krueger, R. A., \& Casey, M. A. (2009). Focus groups: A practical guide for applied research (4th ed.). Thousand Oaks, CA: Sage.

Lee, M.-D. P. (2008). A review of the theories of corporate social responsibility: Its evolutionary path and the road ahead. International Journal of Management Reviews, 10(1), 53-73.

Leedy, P. D. (1997). Practical research: Planning and design. Columbus, OH: Merrill of Prentice Hall.

Lu, J. Y., \& Castka, P. (2009). Corporate social responsibility in Malaysia: Experts' views and perspectives. Corporate Social Responsibility and Environmental Management, 16(3), 146-154.

Mathar, R. (2010). Practices of integrating the earth charter into education activities in German Federal States of Hessen and Rheinland-Pfalz. Journal of Education for Sustainable Development, 4(2), 279-282.

Mitsui \& Co. (2012). Retrieved 15 May, 2012 from http://www. mitsui.co.jp/en/csr/contribution/.

Mohd Ghazali, N. A. (2007). Ownership structure and corporate social responsibility disclosure: Some Malaysian evidence. Corporate Governance, 7(3), 251-266.

Naeem, M. A., \& Peach, N. W. (2011). Promotion of sustainability in postgraduate education in the Asia Pacific region. International Journal of Sustainability in Higher Education, 12(3), 280-290. doi:10.1108/14676371111148063. 
Performance Management and Delivery Unit (PEMANDU). (2010). Economic transformation program. Putrajaya, Malaysia: Performance Management and Delivery Unit (PEMANDU), Prime Minister's Department.

Sampsize. (2005). Retrieved July 9, 2012 from http://sampsize. sourceforge.net/iface/index.html.

Secchi, D. (2007). Utilitarian, managerial and relational theories of corporate social responsibility. International Journal of Management Reviews, 9(4), 347-373.

Siwar, C., \& Hossain, T. M. (2009). An analysis of Islamic CSR concept and the opinions of Malaysian managers. Management of Environmental Quality: An International Journal, 20(3), 290-298.

Siwar, C., \& Md Harizan, S. H. (2009). A study on corporate social responsibility practices amongst business organizations in Malaysia. Bangi: Institute for Environment and Development, Universiti Kebangsaan Malaysia.
Tan, G., \& Komaran, R. (2006). Perception of corporate social responsibility: An empirical study in Singapore. Paper presented at the Thirteenth Annual International Conference on Advances in Management, 26 June, Singapore.

The Prime Minister's CSR Awards. (2010). Retrieved December 9, 2010 from http://www.anugerahcsrmalaysia.org/.

Visser, W. (2008). Corporate social responsibility in developing countries. In A. Crane, A. McWilliams, D. Matten, J. Moon, \& D. Siegel (Eds.), The Oxford handbook of CSR (pp. 473-499). Oxford: Oxford University Press.

Wang, Q. (2011). Characteristics of ESD-promoting strategies in China's basic education. Journal of Education for Sustainable Development, 5(2), 215-223. doi:10.1177/097340821100500211.

Weller, M., \& Dillon, P. (1999). Education and business partnerships in the United Kingdom: Initiatives in search of a rationale. Bulletin of Science, Technology \& Society, 19(1), 60-67. doi: 10.1177/027046769901900110. 